\title{
The Stake of the Junior College in Its Library
}

\begin{abstract}
As in any other institution, a library in a junior college must be determined by the function of its parent organization. Junior colleges have characteristics distinct from those of the four-year college or university. Some of these unique characteristics are discussed, and their meaning to the library is recognized. Recent developments are outlined in intercommunication between junior colleges and their libraries which will improve their articulation.
\end{abstract}

A ing. Learning in the college setting is facilitated by communication among people. Some of the communication is among people who are there in the sense of their physical presence. Among these are students, teachers, and administrators. They ask questions, respond to inquiry, smile, frown, admonish, encourage, criticize. This kind of communication with people in a person-to-person sense represents only a very small fraction of the "meeting of minds" which is basic to college-level learning. Most communication is with people who are not there in person. They are far removed in space and time. Communication with them is established through various symbolic languages which we have learned to use and conserve.

On the printed page-in words, a mathematical equation, a diagram, or a chemical formula, or in a wood carving, a tapestry, an oil painting, or a photograph-are registrations of man's aspirations, perceptions, and accomplishments. Great ideas, some painfully derived, others caught in a flash of insight, have

Mr. Gleazer is Executive Director, American Association of Junior Colleges, Washington, D.C. form and meaning through the many languages man has developed. That learning is effective which takes into account the experiences of others. The museums and libraries of our time make available the experiences of those who have sought truth in the laboratories, defended their concept of freedom in newspapers and in the trenches, sailed ships toward the edge of the world in seas reputed to be the home of monsters, built bridges, flown planes, explored space. These have left their record for others to use, and they invite those who come after them to join in their experiments, share in their disappointments, their fears, and the exhilaration of their discovery. Libraries and museums are often seen as sleepy, dusty, innocuous depositories of miscellaneous artifacts, until someone discovers what the past is really saying.

Richard Llewellyn, in his book How Green Was My Valley, ${ }^{1}$ describes the force with which the page can speak. In the words of Huw Morgan, "Never will I forget the night my father read out of the great man's Letter to the Earl of Chesterfield (Dr. Johnson).

\footnotetext{
${ }^{1}$ Richard Llewellyn, How Green Was My Valley (New York: The Macmillan Company), p. 347-48.
} 
"We sat still when he put down the book, and the room was still, as though in fear, and the very air seemed filled again with the stinging silence there might have been in that house off Fleet Street, on the night when a quill scratched, and eyes looked down at the writing with that calmness and distant cold that comes of prodigious fury long pent and gone to freeze in a dark corner of the mind, yet always kept alive by prodding memory in the volatile spirits of dignity, and now loosed as from the topmost heights of Olympus, each word a laden fireboat, each sentence a joy of draft, the whole a glory of art, this mere rebuke of a lordling, written by the hand that through long, hungry years, had wielded its golden sickle in the chartless wilderness of words.

“. . . So with Dr. Johnson, and John Stuart Mill, and Spencer, and William Shakespeare, and Chaucer, and Milton, and John Bunyan, and others of that royal company of bards, thanks to my father and Mr. Gruffydd, I was acquainted more than plenty of other boys, and thus had a lasting benefit in school."

But everything cannot be gathered together in every institution of learning. There is only one British Museum, only one Smithsonian Institution, only one Library of Congress. Each place of learning defines the resources essential to its purposes, just as it decides the kinds of teachers, and curricula, and students, and facilities, appropriate. It decides in terms of its purposes-what it seeks to do. What does the community junior college do as a place of learning?

\section{The Community College Is Involved in the Process of Social Mobitity}

Regardless of whether they come from a blue-collar or white-collar home-from the upper-upper or lower-lower classes, and some will come from both-those entering America's junior colleges, college-age or older (and who can any longer define "college-age"), are often ambitious toward ends but uncertain of the means by which desirable but vague objectives can be achieved. They will want to sample fields of knowledge-try themselves out, have the privilege of striking out but with another time at bat. Most of them have not packed their trunks to come to this kind of college. They pack their lunch. They work parttime, not so often on the college campus as in stores, plants, service stations, and on the farms of the areas in which they live. They do not return to college residence halls when they have time between classes. They go home, or to the parking lot, or to a job in the community. And at night, they return to the residence in which they lived during their high school days-to the same family they have known through the years-to the same systems of relationships with church, family, other families, and other community institutions.

Many of these students are first generation college-goers. There will be dramatic expansion of these institutions in the major urban areas of this country. The traditions of the home may not be toward an understanding and appreciation of the cultural heritage. Yet there will be minds ready for response if contact can be made.

Large numbers of America's community college students in the decade before us will have neither study space nor materials in their homes. The concepts of Kant, Plato, Jefferson, Michelangelo, Jesus, and Camus are strangers to them. Hosts of thoughtful and provocative minds await introduction to these junior college enrollees. What will be the reaction of these students? Will they be overcome by self-consciousness? Will these unmet but potential colleagues, conveyors of our culture, invite them, persuade them, excite them, or be surrounded by such formality, circumspection, and quiet awe, that academic neophytes will be rebuffed and repelled? 


\section{The Community College Is an Educational Resource Center FOR THE COMMUNITY}

People come to learn for many reasons -some have encountered a problem or an opportunity. Others are questioning or frustrated. Regardless of their age or station in life they may come to the community college. It is a continuing educational resource center. Community colleges may very well come to be major coordinating agencies for continuing education. The college will not be considered so much as a preparatory institution as it will an accessible and available agency to be drawn upon as people have need-people who will come and go and come again.

This kind of college faces the community. Its systems are spliced with those of the community which become its context for learning. It has close relationships with the community orchestra and the art museum and the university extension services. It trains policemen and firemen and technicians for urban renewal. In its halls will be seen enrollees in the job corps and federal retraining programs, persons seeking occupational counseling.

The great issues of each new era are debated in its classrooms and public meeting rooms-Viet-Nam and whatever comes next; the rights and responsibilities of people in the academic community; problems of overpopulation or simply the issue of birth control; how to deal with de facto segregation; and a host of other issues that an alert and responsible citizenry must discuss and analyze-a citizenry that must be informed if discussion is to be more than wallowing in a sea of opinion and prejudgments.

How can the experience of others-for these are not problems totally new and unique to our times-how can the reflections of great minds through the centuries be made available to such a var- iety of people with such a variety of needs?

\section{The Community College Is A DyNAMIC INSTITUTION}

Many forces produce and shape the community college. The aspirations of people for the benefits of education can lead to its establishment. The economic resources of the community engage in continuing mediation with aspirations in determination of the institution's programs and services. Characteristically, the necessity for rapid expansion is an almost inexorable force. At one time, the term junior college was almost synonymous with the term small college. No longer is this true. Not only do pressures for enrollment demand greater capacity but the span of programs required in an "open-door" college, the wealth of resources needed to meet effectively the varied needs of a broad range of students, mean that tomorrow's community college will enroll thousands of students. Some areas will develop several units or campuses in order to distribute educational opportunity more evenly throughout the service area of the institution.

Not only will the community college grow rapidly, but also its very claim to sensitivity and responsiveness to technological, social, and economic shifts in its environment suggest a hospitable attitude toward change. Growth and change are important factors to take into account in any plans for community colleges.

\section{IdENTITY of THE CoMmunity COLLEgE}

This kind of institution has been called a new social invention. It has come into being and evolved in response to societal needs. If not different in kind from other institutions, it is sufficiently different in degree to be recognized as an institution with an identity of its own. Leading architects have recognized this identity and are designing community college 
facilities derived from perception of the distinctive objectives, functions, and hence structures, of this kind of college.

Administrators for community colleges are prepared for community college careers in the Junior College Leadership Program. Similar efforts are under way in the preparation of junior college teachers. If we follow the same lines of logic which have resulted in facility planning for community colleges and preparations of professional personnel for service in community colleges, is it not appropriate to propose that community colleges must have libraries suitable to their singular objectives and functions? It is not enough to borrow the patterns and forms and procedures which may have worked well for other kinds of educational institutions with other assignments and missions. It may be a dangerous fallacy to assume that these will fit the role of the community college. They may or they may not. What is needed is an honest analytical examination of the kinds of library services required to give expression to the community college concept here described.

\section{What Needs to Be Done}

Of all aspects of junior college development, less attention has been given to the junior college library than to any other part of the instructional program. The American Association of Junior Colleges has cooperated in the preparation of book lists and reacted a few years ago to a statement of Standards for Junior Colleges but there had been an absence of constructive, affirmative effort in this important field until just a little over a year ago. At that time, the Council on Library Resources and the Association sponsored a conference on strengthening library services in junior college education.

That historic meeting grew out of the evident need for an informal exchange of ideas relating to problems before junior college administrators and librarians.
Views and recommendations were sought from a select group of presidents, deans, professors, and university and junior college librarians as to the need for and the possible conduct of a proposed year's study of the junior college library. The study would result in "a report which would attempt to identify the role which library services have and potentially can have for junior college education and to provide guidance to junior college administrators for the establishment and operation of libraries in their institutions."

The conference was judged to be highly successful in its frank exchange of views and identification of needs. Unfortunately, the study proposal which developed out of the meeting still awaits funding. In the meantime, the need for such a study has not diminished.

Another important step was taken May 26-28, 1965, when board-level representatives from the American Library Association and the American Association of Junior Colleges met with other interested personnel to discuss junior college library needs. Among the needs agreed to were these:

1. a national conference of junior college administrators and librarians with emphasis upon the changing role of the library on the junior college campus and the emergence of the library as a more closely related instrument in the instructional program;

2. establishment of an organized program for recruitment and preparation of junior college library personnel;

3. lists of materials appropriate to junior college libraries, including those supportive to vocational-technical programs;

4. guidelines to encourage and support effective library services both for new and existing institutions;

5. consultant services;

6. help for facility planning;

7. establishment of a demonstration junior college library.

(Continued on page 317) 
Contents: v.1,pt.1, Do roku 1454. 759p., zł.155; v.1,pt.2, 1454-1795. 399p., zt.86.

These two parts make up Volume I of what is to be a three-volume bibliography of Polish history from earliest times to 1944. The first section of part one is a general guide to bibliographic and reference aids, methodology, historiography, archives and libraries, and auxiliary studies; it is followed by bibliography of Polish history arranged by periods to 1454 , with appropriate subdivisions. Volume I, part 2, continues the period sections to 1795 . (Volume II will deal with Polish history to 1918, and Volume III that of the years following.) While coverage extends to such subjects as statistics, economics, and sociology, the bibliography is meant to be selective rather than exhaustive. Both books and periodical materials are included; the great bulk of entries is, understandably, in Polish. There are some brief annotations and cross references; items are numbered; and an author index is promised.-E.S.

Répertoire méthodique de lhistoire moderne et contemporaine de la France. v.8, Années 1907, 1908 et 1909. Paris: Editions du Centre National de la Recherche Scientifique, 1965. 241p. $20 \mathrm{~F}$.

After an unusual number of delays and vicissitudes this volume, edited from the original research of Pierre Caron and his associates, appears to fill the gap in the series (Guide V235) so that it now offers consecutive coverage for the 18981913 period. The classified arrangement with indexes of authors and persons and of places is consistent with that of the previously published volumes.-E.S.

\section{CHURCH HISTORICAL COLLECTIONS . . .}

(Continued from page 303 )

working with the collection is not a professional librarian, basic rules of filing, cataloging, classification, and preservation must be mastered.

One of the most important things would seem to be to establish a set of rules and organizational procedures to be followed. No collection should be allowed, like Topsy, simply to grow. A mass of unorganized materials is of little value to anyone.

Patrick Henry once said, "I know of no way of judging of the future but by the past." 43 If this be true, it can be concluded that if the various church bodies are to progress in the days to come, they must know their history and heritage. A collection of church historical materials is essential to such knowledge.

4 Patrick Henry, "American Liberty," Great Americans Speak ...., ed. by F. C. Packard (New York: Scribner, ${ }_{[}^{1951_{]}}$), p. 2.

\section{JUNIOR COLLEGE . . .}

\section{(Continued from page 266)}

The people who met in May recommended to their respective boards that a continuing joint committee of AAJC and ALA be established to give leadership to such projects and that some full-time staff services be made available to the committee.

This presentation started with an emphasis upon the importance of communication in the learning process. The events just reported lead to the happy conclusion that communication is improving between professionals who have somewhat different responsibilities on the campus but a common interest in facilitating the learning process through effective and suitable library services.

We can talk to each other. We can listen to each other. We have a basis for understanding. And it is in that kind of climate that we move into this era with the conviction that what we shall do is difficult, but more important, it is essential, and it is time it was done. 